Article

\title{
An Efficient Synthesis of Enantiopure $(R)$-heteroarylpyrimidine Analogs
}

Xiu-Yan Yang ${ }^{1,2, \dagger}$, Guang-Qiang Xia ${ }^{2, \dagger}$, Xiao-Kui Wang ${ }^{2}$, Zhi-Bing Zheng ${ }^{2}$, Dong-Mei Zhao ${ }^{2}$, Guo-Ming $\mathrm{Zhao}^{2, *}$ and Song $\mathrm{Li}^{1,2, *}$

1 School of Pharmaceutical Engineering, Shenyang Pharmaceutical University, Shenyang 110016, China

2 Department of Medicinal Chemistry, Beijing Institute of Pharmacology and Toxicology, Beijing 100850, China

$\dagger$ These authors contributed equally to this work.

* Authors to whom correspondence should be addressed; E-Mails: zhaogm@bmi.ac.cn (G.-M.Z.); lis@bmi.ac.cn (S.L.); Tel.: +86-10-6693-0604 (G.-M.Z.); Fax: +86-10-6821-1656 (G.-M.Z.).

Received: 23 August 2013; in revised form: 3 September 2013 / Accepted: 4 September 2013 / Published: 11 September 2013

Abstract: An efficient synthesis of enantiopure $(R)$-heteroarylpyrimidine analogs is described here, which involves introduction of a chiral group, formation and separation of diasteroisomers and final transformation of an amide to an ester. The absolute configuration of the enantiopure HAPs is confirmed by X-ray analysis of their intermediates.

Keywords: anti-HBV; enantiopure; $(R)$-heteroarylpyrimidines; chiral separation; diastereomer

\section{Introduction}

Chronic HBV infections remain a serious public health problem worldwide. Nucleoside/nucleotide analogs and immune modulators have been approved for the treatment of chronic hepatitis B. Unfortunately, drug resistance and side effects have limited the utility of currently approved drugs [1,2]. Therefore new kinds of anti-hepatitis B agents are still highly desired. Heteroarylpyrimidines (HAPs) were discovered to be a class of highly potent non-nucleoside inhibitors of HBV replication (Figure 1) [3-5]. Bay39-5493 has reached the clinical test stage as an anti-HBV candidate drug. Z060228, another novel 
HAP derivative found by our laboratory, exhibits excellent activity against HBV replication at submicromolar concentration and is currently under preclinical study [6,7].

Figure 1. Structures of HAP analogs.

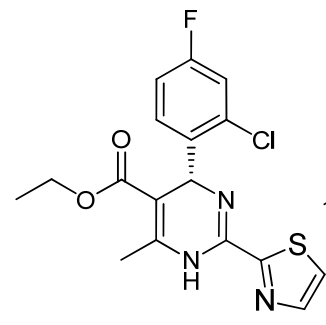

(R)-Bay39-5493

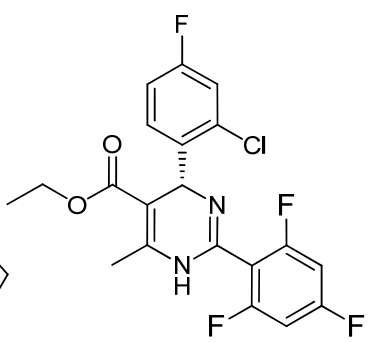

$(R)-Z 060228$

The biological activity of HAPs depends on their absolute configuration and only the $(R)$-enantiomers exhibit anti-HBV activity, so the synthesis of $(R)$-HAPs is necessary for the further drug development. Racemic HAPs were easily prepared from amidine, ethyl acetoacetate and benzaldehyde by a Biginelli reaction (Scheme 1) [8]. However, enantiopure $(R)$-HAPs were difficult to obtain and only Goldman et al. have reported the preparation of $(R)$-Bay39-5493 through a chiral-phase HPLC method $[9,10]$. Herein, we report on a feasible and convenient synthesis of enantiopure $(R)$-HAPs.

Scheme 1. Synthesis of racemic HAPs.

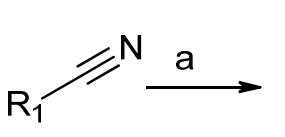

(a) $\mathrm{NH}_{2} \mathrm{OH}$. $\mathrm{HCl} / \mathrm{Na}_{2} \mathrm{CO}_{3} \mathrm{DMSO}$, ambient temperature, overnight; (b) $\mathrm{Ac}_{2} \mathrm{O} / \mathrm{HOAC}$,rt, $30 \mathrm{~min}$;(c) $10 \% \mathrm{Pd} / \mathrm{C} 1 \mathrm{~atm} \mathrm{H}_{2}, 2.5 \mathrm{~h}$; (d) $\mathrm{HOAc} / \mathrm{Py}, \mathrm{EtOH}$, reflux, $20 \mathrm{~h}$;<smiles>[R]C(=O)C1=C(C)NC([R])=N[C@H]1Br</smiles>

Racemic-HAPs (I)

$\mathrm{R}_{1}=\mathrm{Ar}$, heteroAr $\mathrm{R}_{2}=$ Alkoxy

\section{Results and Discussion}

In general, the methods frequently used for the synthesis of enantiopure 1,4-dihydropyridines are the resolution of racemic dihydropyridines, separation via diastereomeric esters, enantioselective synthesis with chiral auxiliary groups, chemoenzymatic separation of dihydropyridines, and chromatographic separation of enantiomers [11-13]. The synthetic strategies we first adopted for the preparation of $(R)$-HAPs involved resolution of the racemic-HAPs I via diastereomeric salts using camphorsulfonic acid as resolution reagent and direct enantioselective synthesis in the chiral environment of quinidine or quinine, but the results were not satisfactory. Then we attempted an indirect method with a chiral auxiliary group to synthesize $(R)$-HAPs as shown in Scheme 2. A chiral group $\mathbf{Y}$ was introduced in starting material and a couple of diasteroisomers II were formed by the Biginelli reaction. The enantiopure IIa and IIb could be separated by taking advantage of the differences in their physiochemical properties and then the enantiopure IIa could be transformed into $(R)$-HAPs after getting rid of the introduced chiral group $\mathbf{Y}$. Apparently, the choice of chiral group $\mathbf{Y}$ is 
key for the whole strategy. According to their cost and practical properties, several chiral agents such as menthol, and mandelic acid were adopted. When menthol was used, the enantiopure IIa or IIb were not crystallized easily from common solvents. When mandelic acid was used, racemization was found to occur under basic conditions. By comparison, $(R)-1$-phenylethanamine was proved to be the suitable chiral agent, which was enantiomerically stable in the subsequent reaction steps and was removed conveniently after enantiopure intermediate IIa was separated.

Scheme 2. Synthetic strategy analysis of enantiopure $(R)$-HAPs.<smiles>[R]C1=N[C@H](Br)C(C(=O)[Y]#C)=C(C)N1</smiles><smiles>[R]C1=N[C@H](Br)C(C(=O)O)=C(C)N1</smiles><smiles>[Y]C(=O)C1=C(C)NC([R])=NC1[Al]</smiles><smiles>[R]C(=O)C1=C(C)NC([R])=N[C@@H]1Br</smiles><smiles>COC1CC(C)CCC1C(C)C</smiles><smiles>CC(C)c1ccccc1</smiles>

$\mathrm{R}_{1}=\mathrm{Ar}$, heteroAr $\mathrm{R}_{2}=$ Alkoxy

With this method $(\boldsymbol{R})$-Z060228 has been synthesized by the synthetic route shown in Scheme 3. In the first step, acylation of $(R)$-1-phenylethanamine $(\mathbf{1},>99 \%$ ee) with diketene (2) easily gave the intermediate $\mathbf{3}$ in $95 \%$ yield [14]. Next, Knoevenagel condensation of $\mathbf{3}$ with 2-chloro-4fluorobenzaldehyde in the presence of acetic acid and piperidine followed by reaction with 2,4,6-trifluorobenzimidamide acetate afforded the diastereomeric 4 in 78\% yield [15-17].

Scheme 3. Synthesis of $(R)-Z 060228$.

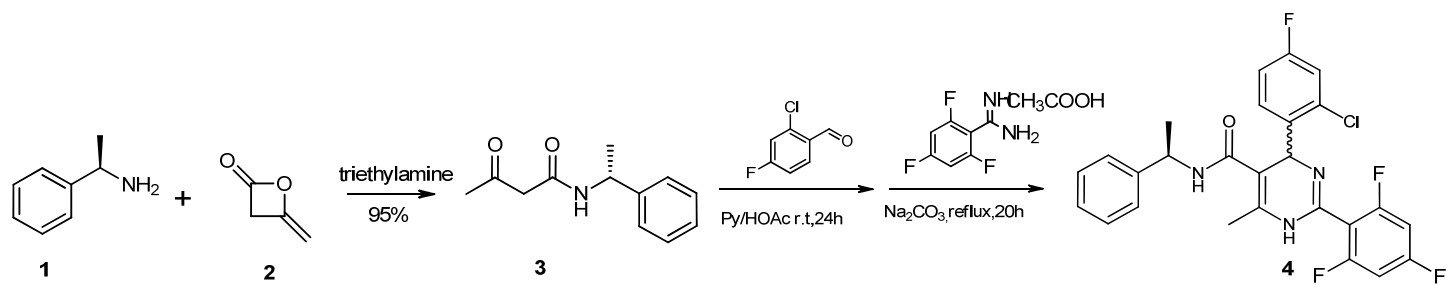<smiles>CC1=C(C(=O)NC(C)c2ccccc2)C(c2ccc(F)cc2Cl)N=C(c2c(F)cc(F)cc2F)N1</smiles><smiles>COc1cc(F)cc(F)c1C1=NC(C)=C(C(=O)NC(C)c2ccccc2)C(c2ccc(F)cc2Cl)N1C(C)=O</smiles><smiles>CC1=C(C(=O)NC(C)c2ccccc2)C(c2ccc(F)cc2Cl)=C(C)NC(c2c(F)cc(F)cc2F)=N1</smiles>

4a<smiles>CCOC(=O)C1=C(C)NC(c2c(F)cc(F)cc2F)=N[C@H]1c1ccc(F)cc1Cl</smiles>

(R)-Z060228 
As we expected, the diastereomers $\mathbf{4 a}$ and $\mathbf{4 b}$ have different solubility in different solvents. Compound 4a was easily crystallized from ethyl acetate, whose de value was $>99 \%$ according to HPLC and then $\mathbf{4 b}$ was easily recrystallized from ethanol.

Next we focused our attention on the transformation of amide 4a into the ester $(\boldsymbol{R})$-Z060228, which was also a key step of the synthetic route. In general, esters aren't easily obtained from the corresponding amides. Alcoholysis of amides, especially for polyfunctional amide was problematic because conventional methods under strongly basic and acidic conditions were only suitable for simple amides and otherwise result in extensive substrate decomposition [18]. What's more, the amide $\mathbf{4 a}$ has lower activity because of its 1,4-dihydropyrimidine ring. In order to improve the reactivity of 4a, introduction of an electron-withdrawing group on the amide- $N$ atom of $4 \mathbf{a}$ was considered Methyl chloroformate and glutaric anhydride were firstly selected as activation reagents, but the results were not satisfactory because of $\mathbf{4 a}$ 's steric effect. Fortunately, we found that $N$-nitrosamide formation was also an efficient method for activation of amides. Nitrosation of secondary amines is usually accomplished using nitrosating agents such as nitrous acid, $\mathrm{NaNO}_{2} / \mathrm{HCl}$, nitrogen oxides $\left(\mathrm{NO}, \mathrm{N}_{2} \mathrm{O}_{3}\right.$ or $\mathrm{N}_{2} \mathrm{O}_{4}$ ) and so on. To improve the yield and avoid the formation of side products, dinitrogen tetroxide was considered as a selective and efficient reagent for N-nitrosation of the secondary amine 4a [19-25].

However, in the course of our experiments, direct $N$-nitrosation of compound $4 \mathbf{a}$ with dinitrogen tetroxide afforded the undesired product $\mathbf{8}$ in almost 100\% yield instead of the desired compound 7. It is noteworthy that this accidental discovery might actually be an excellent method to prepare substituted pyrimidines. According to the analysis of the reaction and the product we concluded that the higher activity of $\mathrm{N}^{1}-\mathrm{H}$ than the amide $\mathrm{N}-\mathrm{H}$ may be the main cause (Scheme 4). To overcome this problem, protection of the amide $\mathrm{N}^{1}-\mathrm{H}$ was required. Acylation of $\mathbf{4 a}$ with acetyl chloride in the presence of triethylamine gave the intermediate 5 in good $95 \%$ yield. $N$-Nitrosation of $\mathbf{5}$ with dinitrogen tetroxide easily gave the intermediate $\mathbf{6}$. Then alcoholysis of crude $\mathbf{6}$ with sodium ethoxide in cold dry DMF afforded the desired compound $(\boldsymbol{R})$-Z060228 in $78 \%$ yield.

Scheme 4. Direct $N$-nitrosation only yielded an arylate product.

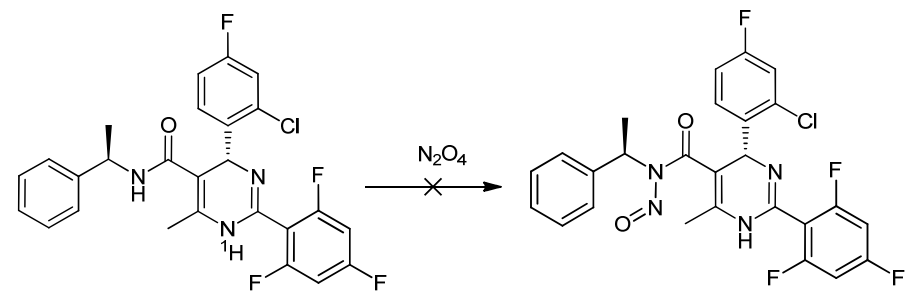

$4 a$

7

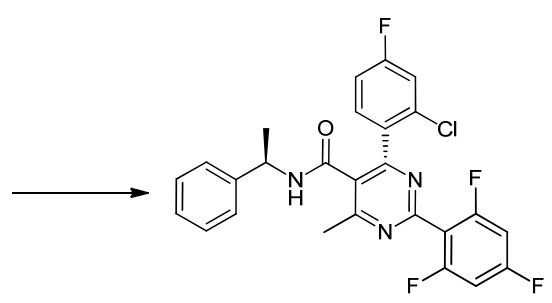


(R)-Z060228's optical purity ( $>99 \%$ ee) was checked with HPLC on a chiral stationary phase (ULTRON ES-OVM $150 \times 4.6 \mathrm{~mm}, 0.01 \mathrm{M} \mathrm{KH}{ }_{2} \mathrm{PO}_{4}: \mathrm{CH}_{3} \mathrm{CN}=90: 10, \lambda=240 \mathrm{~nm}, 1.0 \mathrm{~mL} / \mathrm{min}$ ), which indicated that no racemization occurred in the last two steps. $(\boldsymbol{R})-\mathbf{Z 0 6 0 2 2 8}$ 's specific rotation was found to be $[\alpha]_{\mathrm{D}}^{20}=-92.4\left(\mathrm{c}=1.0, \mathrm{CH}_{3} \mathrm{OH}\right)$ and its absolute $(R)$ configuration could be directly confirmed by determination of the absolute configuration of the intermediate $\left(4 \boldsymbol{R}, 2^{\prime} \boldsymbol{R}\right)-5$ by X-ray crystallography (Figure 2) [26]. Using a similar reaction sequence, Bay39-5493 was prepared in $99 \%$ ee and its specific rotation closely matched the reported value (observed: $[\alpha]_{\mathrm{D}}^{20}=-54.6, \mathrm{c}=1.0$, $\mathrm{CH}_{3} \mathrm{OH}$; lit.: $\left.[\alpha]_{\mathrm{D}}^{20}=-52, \mathrm{c}=1.0, \mathrm{CH}_{3} \mathrm{OH}\right)[27]$.

Figure 2. X-ray crystal structure of the intermediate 5 [28].

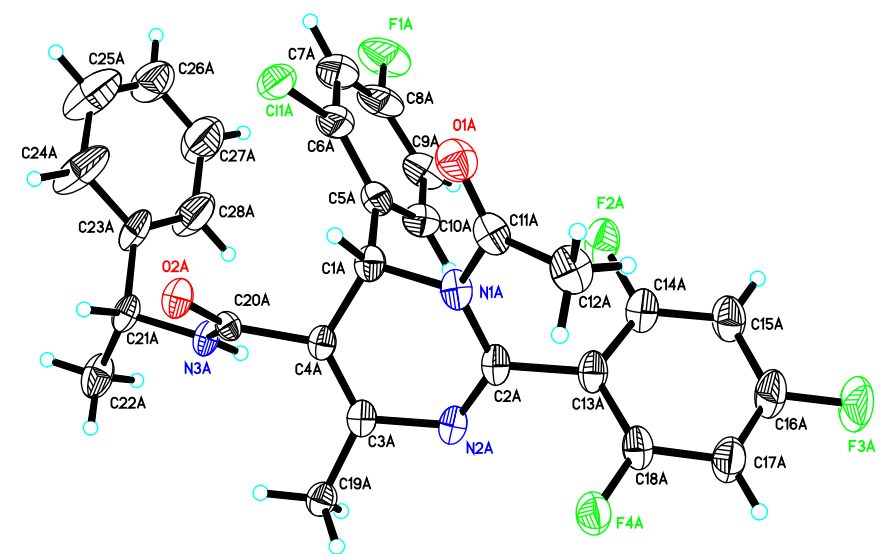

\section{Experimental}

\subsection{General}

${ }^{1} \mathrm{H}-\mathrm{NMR}$ and ${ }^{13} \mathrm{C}-\mathrm{NMR}$ spectra were recorded at $400 \mathrm{MHz}$ and $100 \mathrm{MHz}$ on a JNM-ECA-400 instrument with tetramethylsilane as an internal standard in the DMSO. ESI-MS (high resolution) mass spectra were obtained by using a Waters Xevo G2 Qtof (ESI) mass spectrometer. Melting points were determined using a RY-1 apparatus and are uncorrected.

\subsection{Synthesis}

$R, R-N-(1-P h e n y l e t h y l)-4-(2-c h l o r o-4-f l u o r o p h e n y l)-2-(2,4,6-t r i f l u o r o p h e n y l)-6-m e t h y l-1,4-d i h y d r o-$ pyrimidine-5-carboxamide (4a) and $R, S-N-(1-p h e n y l e t h y l)-4-(2-c h l o r o-4-f l u o r o p h e n y l)-2-(2,4,6-$ trifluorophenyl)-6-methyl-1,4-dihydropyrimidine-5-carboxamide $\quad(\mathbf{4 b}) . \quad(R)-(+)-N$-(1-phenylethyl)3-oxobutyramide (3, $4.50 \mathrm{~g}, 22.05 \mathrm{mmol})$ and 2-chloro-4-fluorobenzaldehyde (3.50 g, $22.05 \mathrm{mmol})$ are dissolved in anhydrous alcohol $(85 \mathrm{~mL})$ containing acetic acid $(1 \mathrm{~mL})$ and piperidine $(1 \mathrm{~mL})$ as catalysts. After stirring at R.T. for $24 \mathrm{~h}, 2,4,6$-trifluorobenzimidamide acetate $(3.51 \mathrm{~g}, 22.05 \mathrm{mmol})$ and sodium acetate $(2.05 \mathrm{~g}, 25.00 \mathrm{mmol})$ are added. After refluxing for $20 \mathrm{~h}$, the reaction mixture is concentrated and the residue is dissolved in water $(50 \mathrm{~mL})$ and extracted with ethyl acetate $(3 \times 25 \mathrm{~mL})$. The combined organic extracts are washed with brine $(20 \mathrm{~mL} \times 3)$ and dried over anhydrous sodium sulfate. After evaporation of the solvent in vacuo, a 1:1 mixture of diastereomeric amides $\mathbf{4 a}$ and $\mathbf{4 b}$ is obtained and subjected to recrystallization from ethyl acetate and pentane (50:50), $4 \mathbf{a}(3.9 \mathrm{~g}, 35 \%)$ is 
isolated as white particles ( $>99 \%$ d.e., according to HPLC). $\mathrm{R}_{\mathrm{f}}=0.34$ (ethyl acetate-petroleum ether $=$ 2:1). Mp $=208-210{ }^{\circ} \mathrm{C} .{ }^{1} \mathrm{H}-\mathrm{NMR}\left(\mathrm{DMSO}-d_{6}\right) \delta: 1.29-1.33(3 \mathrm{H}, \mathrm{m}) ; 1.97(3 \mathrm{H}, \mathrm{s}) ; 4.83-4.87(1 \mathrm{H}, \mathrm{m})$; $5.97(1 \mathrm{H}, \mathrm{s}) ; 7.04-7.06(2 \mathrm{H}, \mathrm{d}, J=6.4 \mathrm{~Hz}) ; 7.12-7.24(7 \mathrm{H}, \mathrm{m}) ; 7.25-7.27(1 \mathrm{H}, \mathrm{m}) ; 8.08-8.10(1 \mathrm{H}, \mathrm{d}$, $J=8 \mathrm{~Hz}) ; 9.24(1 \mathrm{H}, \mathrm{s})$; HRMS (ESI) $\mathrm{m} / z$ : Calcd for $\mathrm{C}_{26} \mathrm{H}_{21} \mathrm{ClF}_{4} \mathrm{~N}_{3} \mathrm{O}, 502.1304[\mathrm{M}+\mathrm{H}]^{+}$; Found: 502.1299 .

The mother liquor was concentrated and redissolved in anhydrous alcohol, whereby $\mathbf{4 b}$ is crystallized (3.43 g, yield $31 \%$ ) as white plates ( $>99 \%$ d.e., according to HPLC). $\mathrm{R}_{\mathrm{f}}=0.36$ (ethyl acetate-petroleum ether $=2: 1) . \mathrm{Mp}=197-199{ }^{\circ} \mathrm{C} .{ }^{1} \mathrm{H}-\mathrm{NMR}\left(\mathrm{DMSO}-d_{6}\right) \delta: 1.17-1.25(3 \mathrm{H}, \mathrm{m}) ; 2.12$ $(3 \mathrm{H}, \mathrm{s}) ; 4.85-4.88(1 \mathrm{H}, \mathrm{m}) ; 6.01(1 \mathrm{H}, \mathrm{s}) ; 7.15-7.20(8 \mathrm{H}, \mathrm{m}) ; 7.86-7.87(2 \mathrm{H}, \mathrm{d}, J=4 \mathrm{~Hz}) ; 7.94-7.95$ $(1 \mathrm{H}, \mathrm{m})$; $9.37(1 \mathrm{H}, \mathrm{s})$; HRMS (ESI) $m / z$ : Calcd for $\mathrm{C}_{26} \mathrm{H}_{20} \mathrm{~N}_{3} \mathrm{OF}_{4} \mathrm{Cl}, 502.1304[\mathrm{M}+\mathrm{H}]^{+}$; Found: 502.1299 .

R,R-N-(1-phenylethyl)-N-1-acetyl-6-(2-chloro-4-fluorophenyl)-2-(2,4,6-trifluorophenyl)-4-methyl-1,6dihydropyrimidine-5-carboxamide (5). A solution of diastereomeric amide 4a (3.03 g, $6 \mathrm{mmol})$ and anhydrous triethylamine $(0.9 \mathrm{~g}, 9 \mathrm{mmol})$ in dry DMF $(45 \mathrm{~mL})$ is stirred at $0{ }^{\circ} \mathrm{C}$, and then acetyl chloride $(0.51 \mathrm{~mL}, 7.2 \mathrm{mmol})$ is added dropwise. After stirring for $6 \mathrm{~h}$, the reaction mixture is quenched with water $(60 \mathrm{~mL})$, and extracted with ethyl acetate $(3 \times 60 \mathrm{~mL})$. The combined organic phase is dried over anhydrous sodium sulfate and concentrated under reduced pressure. The residue is purified by column chromatography on silica gel (ethyl acetate-pentane $=1: 3)$ to give $\mathbf{5}(3.11 \mathrm{~g}, 95 \%)$ as a white powder. $\mathrm{Rf}=0.4$ (ethyl acetate-petroleum ether $=1: 1$ ). Mp: $183-184.2{ }^{\circ} \mathrm{C} .{ }^{1} \mathrm{H}-\mathrm{NMR}$ $\left(\mathrm{DMSO}-d_{6}\right) \delta: 1.39-1.41(3 \mathrm{H}, \mathrm{d}, J=8 \mathrm{~Hz}), 2.07(3 \mathrm{H}, \mathrm{s}), 2.10(3 \mathrm{H}, \mathrm{s}), 4.95-4.99(1 \mathrm{H}, \mathrm{m}), 6.47(1 \mathrm{H}, \mathrm{s})$, 7.08-7.12 (3H, m), 7.15-7.30 (5H, m); 7.45-7.51 (2H, m), 8.70-8.72 (1H, d, $J=8 \mathrm{~Hz})$. HRMS (ESI) $m / z$ : Calcd for $\mathrm{C}_{28} \mathrm{H}_{23} \mathrm{~N}_{3} \mathrm{O}_{2} \mathrm{ClF}_{4}, 544.1409[\mathrm{M}+\mathrm{H}]^{+}$; Found: 544.1398.

Ethyl 4-(R)-(2-chloro-4-fluorophenyl)-2-(2,4,6-trifluorophenyl)-6-methyl-1,4-dihydropyrimidine-5carboxylate (R)-Z060228. To a solution of $\mathbf{5}(2.71 \mathrm{~g}, 5 \mathrm{mmol})$ in dichloromethane $(50 \mathrm{~mL})$ at $0{ }^{\circ} \mathrm{C}$ is added dinitrogen tetroxide $\left(4.60 \mathrm{~g}, 50 \mathrm{mmol}, 10 \mathrm{eq}\right.$.). The solution is stirred under nitrogen at $0{ }^{\circ} \mathrm{C}$ for $20 \mathrm{~h}$ and then poured over ice, and extracted with cold dichloromethane $(2 \times 200 \mathrm{~mL})$, the organic part is concentrated in vacuum in an ice water bath to yield a yellow oil, which is dissolved in cold dry DMF $\left(150 \mathrm{~mL},-40{ }^{\circ} \mathrm{C}\right)$, and sodium ethoxide $(6.8 \mathrm{~g}, 100 \mathrm{mmol}, 20$ eq. $)$ is added. The mixture is stirred for $15 \mathrm{~min}$ under nitrogen atmosphere and then quenched with water $(200 \mathrm{~mL})$ neutralized with $4 \mathrm{M} \mathrm{HCl}$, and extracted with ethyl acetate $(150 \mathrm{~mL} \times 3)$. The combined extracts are dried over anhydrous sodium sulfate, and concentrated at reduced pressure. The residue is purified by column chromatography on silica gel (ethyl acetate-dichloromethane 4:100) to give (R)-Z060228 (1.66 g, $78 \%)$ as a white powder. $[\alpha]_{\mathrm{D}}^{20}=-92.4\left(\mathrm{c}=1.0, \mathrm{CH}_{3} \mathrm{OH}\right),{ }^{1} \mathrm{H}-\mathrm{NMR}\left(\mathrm{DMSO}-d_{6}\right) \delta: 1.02-1.05(3 \mathrm{H}, \mathrm{t})$; $2.32(3 \mathrm{H}, \mathrm{s}) ; 3.92-3.96(2 \mathrm{H}, \mathrm{m}) ; 5.97(1 \mathrm{H}, \mathrm{s}) ; 7.21-7.45(5 \mathrm{H}, \mathrm{m}) ; 9.86(1 \mathrm{H}, \mathrm{s}) .{ }^{13} \mathrm{C}-\mathrm{NMR}\left(\mathrm{DMSO}-d_{6}\right)$ $\delta: 14.4,17.9,56.0,59.6,96.2,101.3,101.5,101.8,115.2,116.6,116.8,131.2,131.2,132.6,139.8$, 142.0, 147.6, 160.0, 162.4, 166.1. HRMS (ESI) $m / z$ : Calcd for $\mathrm{C}_{20} \mathrm{H}_{15} \mathrm{~N}_{2} \mathrm{O}_{2} \mathrm{~F}_{4} \mathrm{Cl}, 427.0831[\mathrm{M}+\mathrm{H}]^{+}$; Found: 427.0827.

Ethyl 4-(R)-(2-chloro-4-fluorophenyl)-2-(thiazol-2-yl)-6-methyl-1,4-dihydropyrimidine-5-carboxylate (R)-Bay39-5493. $[\alpha]_{\mathrm{D}}^{20}=-54.6\left(\mathrm{c}=1.0, \mathrm{CH}_{3} \mathrm{OH}\right) .{ }^{1} \mathrm{H}-\mathrm{NMR}\left(\mathrm{DMSO}-d_{6}\right) \delta: 1.01-1.04(3 \mathrm{H}, \mathrm{m}) ; 2.50$ 
$(3 \mathrm{H}, \mathrm{s}) ; 3.90-3.94(2 \mathrm{H}, \mathrm{m}) ; 5.99(1 \mathrm{H}, \mathrm{s}) ; 7.36-7.43(3 \mathrm{H}, \mathrm{m}) ; 7.90-7.91(1 \mathrm{H}, \mathrm{d}, J=4 \mathrm{~Hz}) ; 7.97-7.98$ $(1 \mathrm{H}, \mathrm{d}, J=4 \mathrm{~Hz})$; $9.96(1 \mathrm{H}, \mathrm{s})$; HRMS (ESI) $m / z$ : Calcd for $\mathrm{C}_{17} \mathrm{H}_{15} \mathrm{~N}_{3} \mathrm{O}_{2} \mathrm{FSCl}, 380.0630[\mathrm{M}+\mathrm{H}]^{+}$; Found: 380.0628 .

\section{Conclusions}

In summary, a novel and efficient approach to the synthesis of enantiomerically pure HAPs is accomplished from inexpensive starting materials. Key feature of this synthesis include an introduction of another chiral group and the alcoholysis to yield the final product. The method described herein could be an attractive alternative for the synthesis of chiral HAPs.

\section{Acknowledgments}

We gratefully acknowledge financial support from the National Nature Science Foundation of China (Grant No.21172263).

\section{Conflicts of Interest}

The authors declare no conflict of interest.

\section{References and Notes}

1. Janssen, H.L.; Van-Zonneveld, M.; Senturk, H.; Zeuzem, S.; Akarca, U.S.; Cakaloglu, Y.; Simon, C.; So, T.M.; Gerken, G.; de Man, R.A.; et al. Pegylated interferon alfa-2b alone or in combination with lamivudine for $\mathrm{HBeAg}$-positive chronic hepatitis B: A randomised trial. Lancet 2005, 365, 123-129.

2. Zoulim, F.; Poynard, T.; Degos, F.; Slama, A.; El Hasnaoui, A.; Blin, P.; Mercier, F.; Deny, P.; Landais, P.; Parvaz, P.; et al. A prospective study of the evolution of lamivudine resistance mutations in patients with chronic hepatitis B treated with lamivudine. J. Viral. Hepat. 2006, 13, $278-288$.

3. Hacker, H.J.; Deres, K.; Mildenberger, M.; Schröder, C.H. Antivirals interacting with hepatitis B virus core protein and core mutations may misdirect capsid assembly in a similar fashion. Biochem. Pharmacol. 2003, 66, 2273-2279.

4. Stray, S.J.; Bourne, C.R.; Punna, S.; Lewis, W.G.; Finn, M.G.; Zlotnick, A. A heteroaryldihydropyrimidine activates and can misdirect hepatitis B virus capsid assembly. Proc. Natl. Acad. Sci. USA 2005, 102, 8138-8143.

5. Bourne, C.R.; Finn, M.G.; Zlotnick, A. Global Structural Changes in Hepatitis B Virus Capsids Induced by the Assembly Effector HAP1. J. Virol. 2006, 80, 11055-11061.

6. Li, S.; Zhao, G.M; Xia, G.Q. Dihydropyrimidine compounds and their uses in preparation of medicaments for treating and preventing antiviral diseases. U.S. Patent 8168642 B2, 1 May 2012.

7. Zhao, G.M.; Wang, X.K.; Ju, X.J.; Guan, H.; Zhong, W.; Wang, L.L.; Xiao, J.H.; Yang, X.H.; Li, S. Synthesis and Anti-HBV Activity of Novel Dihydropyrimidine Analogs. Scientia Sinica Vitae 2011, 41, 971-977. 
8. Deres, K.; Schroder, C.H.; Paessens, A.; Goldmann, S.; Hacker, H.J.; Weber, O.; Krämer, T., Niewöhner, U.; Pleiss, U.; Stoltefuss, J.; et al. Inhibition of hepatitis B virus replication by drug-induced depletion of nucleocapsids. Science 2003, 299, 893-896.

9. Goldmann, S.; Stoltefuss, J.; Niewohner, U.; Schelemmer, K.H. Dihydropyrimidines and the use thereof as medicaments for the treatment of hepatitis B. DE 10012824A1, 20 September 2001.

10. Goldmann, S.; Stoltefuss, J.; Paessens, A.; Graef, E.; Lottmann, S. 2-heterocyclically substituted dihydropyrimidines. U.S. Patent 6503913B1, 7 January 2003.

11. Evans, P.A.; Qin, J.; Robinson, J.E.; Bazin, B. Enantioselective total synthesis of the polycyclic guanidine-containing marine alkaloid (-)-batzelladine D. Angew. Chem. Int. Ed. 2007, 46, 7417-7419.

12. Kamaljit, S.; Divya, A.; Danielle, F.; Liu, Q.X.; Moreland, R.S. An Efficacious Protocol for 4-Substituted 3,4-Dihydropyrimidinones: Synthesis and Calcium Channel Binding Studies. Eur. J. Org. Chem. 2009, 19, 3258-3264.

13. Siegfried, G.; Jiirgen, S. 1,4-Dihydropyridines: Effects of Chirality and Conformation on the Calcium Antagonist and Calcium Agonist Activities. Angew. Chem. Inr. Ed. Engl. 1991, 30, 1559-1578.

14. Hudlicky, T.; Gillman, G.; Andersen, Catherine. Homochiral amine synthesis by baker's yeast resolution of a $\beta$-keto amide: 1-Phenylethylamine. Tetrahedron Asymmetry 1992, 3, 281-286.

15. Slee, H.D.; Chen, Y.; Zhang, X. 2-Amino- $N$-pyrimidin-4-ylacetamides as A2A receptor antagonists: 1. Structure-activity relationships and optimization of heterocyclic substituents. J. Med. Chem. 2008, 51, 1719-1729.

16. Judkins, B.D.; Allen, D.G.; Cook, T.A. A Versatile Synthesis of Amidines from Nitriles Via Amidoximes. Synth. Commun. 1996, 26, 4351-4367.

17. Zhu, X.J.; Zhao, G.M.; Li, S. 2,4-Diaryl-4,6,7,8-tetrahydroquinazolin-5(1 H)-one derivatives as anti-HBV agents targeting at capsid assembly. Med. Chem. Lett. 2010, 20, 299-301.

18. Evans, D.A.; Carter, P.H.; Dinsmore, C.J.; James, C.B.; Jeffrey, L.K.; Daniel, W.K. Mild nitrosation and hydrolysis of polyfunctional amides. Tetrahedron Lett. 1997, 38, 4535-4538.

19. Julio, C.; Albino, C.; Ramon Leis, J.; Manuel, M.; Pena, M.E. Kinetic Studies on the Formation of $N$-Nitroso Compounds X. The Nitrosation of $N$-Methylacetamide and Its Differences with Respect to the Nitrosation of Amines. Monatshefte für Chemie 1984, 115, 1047-1057.

20. Nasser, I.; Habib, F.; AliReza, P. Dinitrogen Tetroxide - Impregnated Charcoal $\left(\mathrm{N}_{2} \mathrm{O}_{4} /\right.$ Charcoal): Selective Nitrosation of Amines, Amides, Ureas, and Thiols. Synth. Commun. 2005, 35, 1517-1526.

21. Hoang-V.L.; Li, J.F.; Bruce, G. A practical and inexpensive 'convertible' isonitrile for use in multicomponent reactions. Tetrahedron Lett. 2011, 52, 2209-2211.

22. Fujita, D.; Suzuki, K.; Sato, S.; Maho, Y.U.; Kurimoto, E.; Yamaguchi, Y.; Kato, K.; Fujita, M. Synthesis of a Bridging Ligand with a Non-denatured Protein Pendant: Toward Protein Encapsulation in a Coordination Cage. Chem. Lett. 2012, 3, 313-315.

23. Monika, C.; Alexis, B.; Caroline, W.; Martial, T.; Jérôme, B.; Caroline, W.; Krzystof, L.; Isabelle, G. $\mathrm{P}-\mathrm{C}$ Cross-Coupling Onto Enamides: Versatile Synthesis of $\alpha$-Enamido Phosphane Derivatives. Eur. J. Org. Chem. 2012, 6, 1101-1106. 
24. Daniel-S, L.; Anupong, T.; Ramajeyam, S.; Taylor, M.T.; Fox, J.M.; Ting, A.Y. Diels-Alder cycloaddition for fluorophore targeting to specific proteins inside living cells. J. Am. Chem. Soc. 2012, 134, 792-795.

25. Bisset, A.; Desmond, L.; Clarkson, J.; Dishington, A.; Jones, T.; Clarkson, G. J.; Ikariya, T.; Wills, M. Synthesis and asymmetric hydrogenation of (3E)-1-benzyl-3-[(2-oxopyridin-1(2H)yl)methylidene]piperidine-2,6-dione. Chem. Comm. 2012, 48, 11978-11980.

26. Yang, X.Y.; Zhao, G.M.; Yang, S.Y. Synthesis and Crystal Structure of $(R)$-1-acetyl-6-(2-chloro4-fluorophenyl)-4-methyl-N-((R)-1-phenylethyl)-2-(2,4,6-trifluorophenyl)-1,6-dihydropyr-imidine5-carboxamide. Chin. J. Struct. Chem. 2013, 32, 989-992.

27. Weber, O.; Schlemmer, K.-H.; Hartmann, E.; Hagelschuer, I.; Paessens, A.; Graef, E.; Deres, K.; Goldmann, S.; Niewoehner, U.; Stoltefuss, J.; et al. Inhibition of human hepatitis B virus (HBV) by a novel non-nucleosidic compound in a transgenic mouse model. Antiviral Res. 2002, 54, 69-78.

28. CCDC 908381 contains the supplementary crystallographic data for this paper. These data can be obtained free of charge from The Cambridge Crystallographic Data Centre via www.ccdc.cam.ac.uk/data_request/cif.

Sample Availability: Samples of the compound (R)-Z060228 are available from the authors.

(C) 2013 by the authors; licensee MDPI, Basel, Switzerland. This article is an open access article distributed under the terms and conditions of the Creative Commons Attribution license (http://creativecommons.org/licenses/by/3.0/). 